\title{
BOARD OF DIRECTORS EFFECTIVENESS, VOLUNTARY INTEGRATED REPORTING AND COST OF EQUITY: EVIDENCE FROM OECD COUNTRIES
}

\author{
Mira Falatifah* \\ Universitas Indonesia \\ Ancella Anitawati Hermawan \\ Universitas Indonesia
}

\begin{abstract}
This study aims to examine the effect of the board of directors effectiveness on the level of integrated reporting disclosure. The study also examined the effect of the level of disclosure on integrated reporting on cost of equity. Further, examine the effect of the board of directors effectiveness on cost of equity through the level of disclosure of integrated reporting. Board of directors effectiveness which is a corporate governance structure can be seen from the components of independence, activity, size and competence. Hypothesis testing is carried out by using a Structural Equation Modelling (SEM) model of 373 observations (firm-year) with the sample taken from more than 20 Organization for Economic Co-operation and Development (OECD) countries where the companies listed on The International Integrated Reporting Council (IIRC) during the period 2015-2017. The results of this study evidence that the level of integrated reporting disclosure has an effect on reducing the company cost of equity. However, the result for the influence of the board of directors effectiveness are still mixed. The findings indicate that the effectiveness of the board of directors does not affect the level of integrated reporting disclosure. And there is no significant influence between board of directors effectiveness, level of integrated reporting disclosure and cost of equity. Perhaps one of the factors for this lack of influence is that the sample data in this study are companies that are still voluntarily disclosing their integrated reporting so that the board of directors still does not feel pressured to disclose integrated reporting. And in the end it cannot yet be seen in relation to the decrease in equity costs.
\end{abstract}

Keywords: Board of Directors Effectiveness; Integrated Reporting; Cost of Equity.

Received: 19 January 2019

Accepted:30 December 2020

https://doi.org/10.33736/ijbs.3188.2021

\section{INTRODUCTION}

Integrated Reporting (IR) is the latest type of reporting that has been widely applied by various companies in various countries to date. IR is a mechanism in presenting information of company related to strategy, governance, performance and prospects related to each other in a single report (IIRC, 2011).

\footnotetext{
* Corresponding author: Universitas Indonesia, Jl. Margonda Raya, 16424, Depok, Indonesia; Tel: (+62) 217867222; E-mail: falatifah.mira@gmail.com
} 
IR is not only limited to producing integrated reports, but the essence is that companies can review and re-evaluate their business activities in the context of sustainable value creation, to short, medium and long term. IR contributes to improving the quality of information presented by a company (IIRC, 2013). This is intended to make information reporting better along with the demands and needs of various parties. In fact, until now, the company still presents annual reports and sustainability reports separately. The annual report, which emphasizes financial statements (financial reports) is aimed more at the owners of capital.

Many opinions contradict the form of separate reports (financial reports and sustainability reports) from various parties. Because the information presented does not have a link between one report and another (Berndt, Bilolo, \& Muller, 2014). This creates difficulties for stakeholders to analyze available information related to decision making. Investors find it difficult to understand how nonfinancial performance is related to financial performance, as well as the contribution of nonfinancial performance in the creation of corporate value (Eccles \& Serafeim, 2014). The company presents two reports that contain different information and cannot be linked to both. So that annual reports and sustainability reports need to be integrated into a single report called integrated report (Eccles \& Krzus, 2010). Van Zyl (2013) found that the current level of report integration is relatively low and companies only disclose the minimum required information.

PWC (2013) and Deloitte (2014) found that governance has a great opportunity for further development according to the IR Framework. One of the corporate governance structures can be seen from the Board of Directors (BoD). BoD effectiveness can encourage companies to improve their performances, one of them is by implementing company reporting that is not only mandatory but also voluntary. In addition, according to signaling theory, by disclosing IR, companies try to convey positive signals to investors, through the disclosure of integrated company information. So that it is expected to reduce information asymmetry felt by investors which will then have an impact on increasing market liquidity which will then reduce the company cost of equity. According to research from Yoo and Semenenko (2012), Saini and Herrmann (2013), Blanco, Lara and Tribo (2015) agree that there is a negative relationship between information disclosed with the cost of equity.

According to Haji and Anifowose (2016) for research examining the relationship between corporate governance structure and the level of IR disclosure is still very rarely done and Hoque (2017) suggests that further research can test the relationship. In addition, research from de Villiers, Hsiao, and Maroun (2017) construct a conceptual model related to factors that influence IR and suggest further research to examine the effect of governance on IR. So, this study also examines the relationship between governance structures in this case BoD effectiveness, the level of IR disclosure, and cost of equity both direct and indirect. This is one of the previous research gaps that was tried to be raised in this study. The novelty in this study is to show an indirect relationship between $\mathrm{BoD}$ effectiveness and cost of equity through mediating the level of IR disclosure. So that it becomes a contribution to this research that examines BoD effectiveness, level of IR disclosure, and cost of equity together.

This study aims to provide empirical evidence on the effect of BoD effectiveness on cost of equity, and the role of level of IR disclosure in mediating those influences. Based on signaling theory, this study developed hypotheses. This study used panel data from 373 observations (firm-year) with 
the sample taken from more than 20 Organization for Economic Co-operation and Development (OECD) during the period 2015-2017. Using Structural Equation Modeling (SEM) analysis, this study found that BoD effectiveness does not affect level of IR disclosure. However, level of IR disclosure has a negative effect on cost of equity. This study also found that level of IR disclosure cannot mediate the effect of BoD effectiveness against cost of equity. The results of this study have implications for regulators in terms of considering to implementing a mandatory policy for IR disclosure. Because according to the results of this study it is proven that IR disclosure has a significant influence in reducing cost of equity.

\section{LITERATURE REVIEW}

\section{$2.1 \quad$ Board of Directors Effectiveness and Signalling Theory}

Corporate governance is a transparent process or mechanism for determining effective and efficient corporate objectives, achieving performance, and measuring its performance. This is related to the rights of stakeholders to get the fit and correct information at the time that is needed, so that it helps stakeholders in making decisions (Mallin, 2013). A good corporate governance mechanism can be seen from the effectiveness of Boards of Directors (BoD) which will lead to effective supervision.

The BoD on the unitary board system consists of executives and non-executive boards. The effectiveness of the board in carrying out its role can be influenced by the characteristics of the board. Hermawan (2011) uses several board characteristics (i.e. independence, activity, size, and competence) to measure board effectiveness. Independence: With the presence of independent $\mathrm{BoD}$ members who meet the criteria, the function of the $\mathrm{BoD}$ is expected to be more effective because independent BoD members do not have a conflict of interest when carrying out their duties (Hermawan, 2011). Activities: Meetings that often meet have a more effective role because they can better monitor the company (Lipton \& Lorsch, 1992). Size: The addition of BoD member can increase the monitoring role more effectively (Klein, 2002) and (Qin \& Tan, 2007). Competence: The effectiveness of the monitoring board role depends on their experience, knowledge, and educational background so that they can have the ability to understand the company's business operations and have the competence in understanding the company's financial statements (Hermawan, 2011). From the point of view of signaling theory, the BoD will tend to carry out effective supervision to convey positive signals and with the positive signals delivered by the company can reduce information asymmetry between companies and investors so that it is expected to provide benefits for the company.

\subsection{Integrated Reporting Disclosure and Signalling Theory}

Integrated reporting (IR) combines a number of reports (financial, management records, governance and remuneration, and sustainability reporting) into one reporting package to explain ability of the organization to create value and maintain its value in the long term. Serve together material information about the strategy, governance and remuneration, performance, risk and prospects of an organization that reflects the commercial, social and environmental context in which the organization operates. 
IR adoption in the future is expected to overcome a number of problems in conventional reporting, namely stand-alone sustainability reports, such as failure to explain all the resources that create value, complex relationships between sustainability and financial performance, and effective communication in the company's business model (Eccles \& Krzus, 2010). IR contributes to improving the quality of information presented by companies (IIRC, 2013). So that by increasing the quality of company information will increase the trust of investors. With the growing trust of investors, it will provide benefits to the company to short, medium and long term. In accordance with IR objectives that are expected to create company value over time.

In addition, according to the signalling theory, by disclosing integrated reporting the company tries to convey a positive signal to investors, with the disclosure of integrated company information. Voluntary disclosure of company reporting is considered more as a positive signal by investors than the disclosure of mandatory corporate reporting. According to research from Yoo and Semenenko (2012), Saini and Herrmann (2013), Blanco et al., (2015) agree that there is a negative relationship between capital costs and information disclosed.

\subsection{Research Framework}

The framework that describes this research is as follows:

Figure 1: Interrelation between board of directors effectiveness, level of integrated reporting and cost of equity

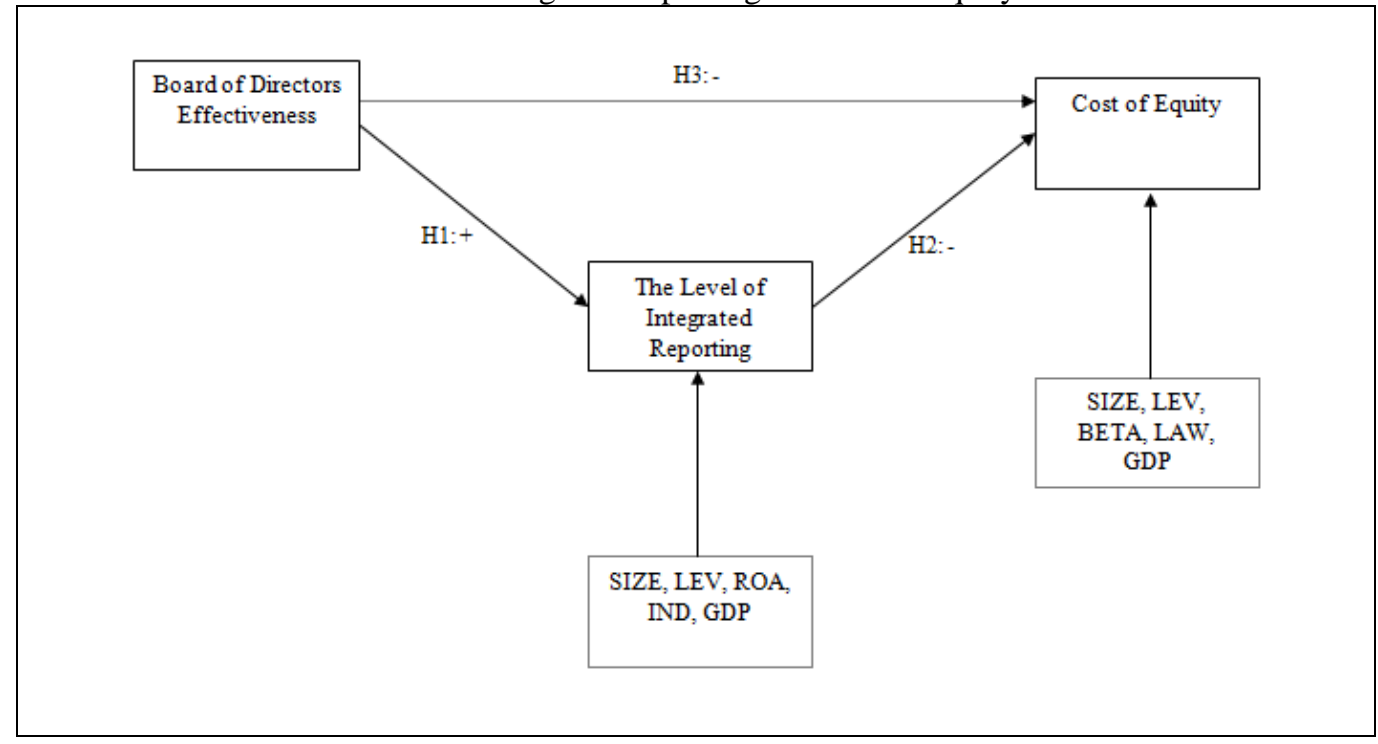

\subsection{Hypothesis Development}




\subsubsection{Board of Directors Effectiveness and Level of Integrated Reporting Disclosure}

According to research from EY (2014) that level of integrated reporting (IR) disclosure varies in various countries. The level of IR disclosure is influenced by many factors, one of which is the corporate governance structure factor. Effective corporate governance can strengthen internal control of the company, so that the company will disclose more information to reduce problems that might arise from opportunistic behaviour and from the existence of information asymmetry, as revealed through integrated reporting (Frías-Aceituno, Rodríguez-Ariza, \& García-Sánchez, 2013). A good corporate governance mechanism can be seen from the effectiveness of the board of directors, which will lead to effective supervision in terms of the level of disclosure of company reports, one of which is IR. Signaling theory encourages companies to disclose IR extensively. With the existence of IR that are disclosed extensively and in accordance with the IR framework, it will be a positive signal to the public, especially investors. That the company is committed to doing the best in terms of corporate reporting.

Research from Dias, Rodrigues and Craig (2017) says that voluntary disclosure is positively influenced by corporate governance characteristics, one of which is board size and CEO duality. That the larger the size of the board will be able to represent the extent of the differences that exist from the stakeholders and will also encourage better supervision, better management of stakeholders, more transparent management, and increase corporate disclosure. DeVilliers et al. (2017) and Velte and Stawinoga (2016) study that corporate governance structures have a large impact on IR and board composition is the main legitimacy aspect of corporate governance both in one-tier and two-tier system. Research from Kilic and Kuzey (2018) shows that BoD characteristics have a positive effect on the level of corporate disclosure. However, this study did not find a significant impact of several other BoD characteristics such as the size and composition of the $\mathrm{BoD}$ on the level of corporate disclosure.

According to the previous literature that research examining corporate governance structure on the level of IR disclosure results in diverse conclusions and research is still very rarely done. Whereas a good corporate governance mechanism that can be seen from BoD effectiveness can lead to effective supervision in terms of the level of disclosure of company reports, one of which is IR. Based on the description, the hypothesis developed is:

\section{H1: Board of directors effectiveness has a positive effect on the level of integrated reporting disclosure.}

\subsubsection{Level of Integrated Reporting Disclosure and Cost of Equity}

Research by Ng and Rezaee (2015) examines whether and how voluntary disclosure, namely Environmental, Social and Governance (ESG) interactively impacts the cost of equity capital. It found that reporting ESG performance was negatively related to the cost of equity capital. The study also found that ESG's interactive performance reporting impacts on equity costs. Operating efficiency is positively related to the cost of equity.

The IIRC framework has two objectives related to IR, to improve the quality of information for the needs of external financial capital providers and to assist in making better decisions by internal 
management. For this reason Barth, Cahan, Chen, and Venter (2017) conducted further research to continue the previous research, which examined the relationship between the level of IR disclosure and firm value by agreeing on two channels, capital market channel and real effects channel. The aim of that study is to examine the extent of the influence of IR level disclosure is on higher firm value. Barth et al., (2017) separates firm value become three determinants, liquidity, cost of capital, and expected future cash flows. Barth et al., (2017) find a positive relationship between level of IR disclosure and liquidity - a capital market effect, and between level of IR disclosure and expected future cash flows. But the study finds no evidence of a relationship between level of disclosure of IR and cost of capital. However, this study aims to examine further the effect of level of IR disclosure on cost of equity, that has not been successfully proven by research from Barth et al., (2017). In particular, his research found a positive relationship between IRQ and liquidity, and between IRQ and expected future cash flowing.

Based on signalling theory, companies make IR disclosures to give positive signals to stakeholders, especially investors that by following the latest reporting mode, namely IR, and applying it extensively the company tries to show that management can realize the owner's wishes and can state the company's condition better from other companies and investors will more easily understand the information disclosed by the company through IR. This signal shows that the company is able to commit to maintaining the sustainability of its business operations compared to other companies that are difficult to imitate the behavior ( $\mathrm{Ng} \&$ Rezaee, 2015).

Based on the description, there are still various research results related to the relationship between the quality of information disclosure and the cost of equity, and there is still very little research that examines the direct relationship between the level of IR disclosure and the cost of equity, so the hypothesis developed is:

\section{H2. Level of integrated reporting disclosure has a negative effect on cost of equity}

\subsubsection{Board of Directors Effectiveness, Level of Integrated Reporting Disclosure, and Cost of Equity}

Effective corporate governance (measured by board size, independence, activity, and diversity of members) can strengthen the company's internal control so that the company will disclose more information to reduce problems that might arise from opportunistic behavior and from the existence of information asymmetry, as revealed through integrated reporting (Frías-Aceituno et al., 2013).

As explained earlier that one of the objectives of this study was to empirically examine the effect of BoD effectiveness on cost of equity through the level of IR disclosure. Related to the results of the study examining the $\mathrm{BoD}$ effectiveness relationship to the cost of equity both research from Gupta, Krishnamurti, and Tourani-Rad (2018) and from Mazzotta and Veltri (2014) show that there is a positive relationship between the corporate governance structure and level of disclosure of integrated reporting, the more effective corporate governance in this case the BoD effectiveness will encourage companies to disclose IR well, accordance with the applicable IR framework.

According to a study from Hermawan (2011), the existence of governance structures has an impact on the better monitoring function of the financial reporting process. Not only in financial reporting, 
the existence of governance structures also has an impact on the better supervision function of the IR disclosure of a company. Given the extensive level of IR disclosure, it will be a positive signal to external parties. Thus, it can reduce information asymmetry between management and external parties. In the end the company cost of equity decreased. This can occur through a decrease in transaction costs or through an increase in demand for company securities. So that the level of IR disclosure can be a mediation on the effect of BoD effectiveness in reducing the company cost of equity. But so far no research has been found that examines the effect of BoD effectiveness and the level of IR disclosure on corporate equity costs together. Based on the above explanation, the following hypothesis was developed:

\section{H3: Board of directors effectiveness has a negative effect on cost of equity through level of integrated reporting disclosure.}

\section{METHODOLOGY}

\subsection{Data and Sample}

The sample in this study are companies that disclose voluntary integrated reporting. The company is spread in more than 20 countries which are member of the OECD and listed in IIRC database. These countries include: Australia, Austria, Belgium, Brazil, Colombia, Finland, France, Germany, Greece, Hong Kong, India, Italy, Japan, Luxembourg, Malaysia, Netherlands, Singapore, Slovenia, Spain, Sri Lanka, Sweden, Switzerland, United Kingdom and the United States. The financial sector was excluded from this study because this sector has a highly regulated character. This is done to maintain the homogeneity of variable interpretations.

The initial sample in this study amounted to 355 companies. Companies that include the financial sector consist of 48 companies. And companies that do not have complete data as many as 161 companies are excluded from the sample. The sample used was 146 companies, with a total observation of 373 observations for 2015-2017, using unbalanced panel data because of the difference in the number of time units for each individual company.

\subsection{Data Collection Method}

This study uses secondary data sources, data that is not directly obtained from the source but from intermediary media or other parties. Secondary data used in this study were obtained from integrated reports from companies listed on the IIRC database in 2015-2017. The data needed for this study was taken from Thompson Reuters and World Bank database. This research is quantitative empirical research. Data related to integrated reporting and data of board of directors are obtained from the website of each company. Cost of equity and other data were obtained from the Thompson Reuters and World Bank database.

\subsection{Research Model}

Hypothesis 1 was tested using model-1 as follows (Model 1): 


$$
\text { IRScore }_{i t}=\beta_{0}+\beta_{1} \text { BoardScore }_{i t}+\beta_{2} \text { Size }_{i t}+\beta_{3} \text { ROA }_{i t}+\beta_{4} \mathrm{LEV}_{\text {it }}+\beta_{5} \mathrm{IND}_{\text {it }}+\beta_{6} \mathrm{GDP}+e_{\mathrm{it}}
$$

Hypotheses 2 and 3 were tested using model-2 as follows (Model 2):

$$
\begin{gathered}
\mathrm{COE}_{\mathrm{it}}=\beta_{0}+\beta_{1} \text { BoardScore }_{i t}+\beta_{2} \mathrm{IRScore}_{i t}+\beta_{3} \text { Size }_{\text {it }}+\beta_{4} \mathrm{LEV}_{\mathrm{it}}+ \\
\beta_{5} \mathrm{BETA}+\beta_{6} \mathrm{LAW}+\beta_{7} \mathrm{GDP}+e_{\mathrm{it}}
\end{gathered}
$$

\begin{tabular}{|c|c|}
\hline Variable & Description \\
\hline IRSCORE it & $\begin{array}{l}\text { The score of integrated reporting disclosure is measured using } \\
\text { keywords searches referring to IIRC (2013); Zhou, Simnett and } \\
\text { Green (2017); Fernando (2018), with NVIVO } 10 \text { software. }\end{array}$ \\
\hline $\mathrm{COE}$ & $\begin{array}{l}\text { Cost of equity, the data is measured using the Capital Asset } \\
\text { Pricing Model (CAPM) approach (Sharpe-Lintner-Mossin } \\
\text { model), obtained from Thompson Reuters database. }\end{array}$ \\
\hline$\beta_{0}$ & Intercept of each regression equation \\
\hline$\beta_{1}, \ldots, \beta_{\mathrm{n}}$ & Regression coefficient of independent variables \\
\hline BOARDSCORE $_{i t}$ & $\begin{array}{l}\text { Score of Board of Directors effectiveness measured by content } \\
\text { analysis based on Hermawan (2011). Consist of independence, } \\
\text { activity, size and competence. }\end{array}$ \\
\hline $\mathrm{SIZE}_{\mathrm{it}}$ & $\begin{array}{l}\text { Firm size is measured using natural logarithms of the total assets } \\
\text { (Baboukardos \& Rimmel, 2016; García-Sánchez \& Noguera- } \\
\text { Gámez, 2017; Lee \& Yeo, 2016; and Kilic \& Kuzey, 2018). }\end{array}$ \\
\hline $\mathrm{LEV}_{\text {it }}$ & $\begin{array}{l}\text { Leverage is measured by using ratio of total liabilities to total } \\
\text { assets (Haji \& Anifowose, 2016; Lee \& Yeo, 2016; Ng \& Rezaee, } \\
\text { 2015). }\end{array}$ \\
\hline BETA $_{\text {it }}$ & $\begin{array}{l}\text { Data investment risk is taken from Thompson Reuters Database. } \\
\text { Based on Ng and Rezaee (2015) and Mazzotta and Veltri (2012). }\end{array}$ \\
\hline $\mathrm{LAW}_{\text {it }}$ & $\begin{array}{l}\text { Dummy variable which is the country level control variable, which } \\
\text { shows the basis of the legal system used, value } 1 \text { if adhering to } \\
\text { civil law, and } 0 \text { if otherwise. Refers to Gupta et al. (2018). }\end{array}$ \\
\hline $\mathrm{GDP}_{\text {it }}$ & $\begin{array}{l}\text { Gross Domestic Product, which is a country level control variable, } \\
\text { data is taken from the World Bank Database, referring to } \\
\text { Emanuele (2016). }\end{array}$ \\
\hline $\mathrm{ROA}_{\text {it }}$ & $\begin{array}{l}\text { Level of corporate profitability as measured by the ratio of net } \\
\text { profit divided by total assets (Kilic \& Kuzey, 2018; Frías-Aceituno } \\
\text { et al., 2013; Haji \& Anifowose, 2016). }\end{array}$ \\
\hline IND $_{\text {it }}$ & $\begin{array}{l}\text { Industry, an industrial dummy variable that is worth } 1 \text { if the firm } \\
\text { is in the manufacturing industry and } 0 \text { otherwise, based on } \\
\text { research from Kilic \& Kuzey (2018); Frías-Aceituno et al. (2013); } \\
\text { and Baboukardos \& Rimmel (2016). }\end{array}$ \\
\hline$e_{\mathrm{it}}$ & Error coefficient \\
\hline
\end{tabular}

Table 1: Description of Variables in the Model

\subsection{Operational Variable}

\subsubsection{Dependent Variable: Cost of Equity (CAPM)}


Data related to cost of equity was obtained from Thompson Reuters Database. The data is measured using the Capital Asset Pricing Model (CAPM) approach. This method not only calculates the rate of return, but also determines the worth of an investment. The CAPM measurement formula follows the formula developed by Sharpe (1964), Lintner (1965) and Mossin (1969), as follows:

$$
\mathrm{COE}=\mathrm{Rf}+(\mathrm{E}(\mathrm{Rm})-\mathrm{Rf}) \beta
$$

Information:

$\mathrm{COE}=$ Cost of Equity. The level of return on securities, this value is used as a proxy for the cost of equity, which is the expected rate of return.

$\mathrm{Rf} \quad=$ Risk free rate, which is the rate of return on risk-free assets.

$\mathrm{E}(\mathrm{Rm})=$ Market risk premium expectations, which are calculated by reducing market risk with risk free rates.

$\beta \quad=$ Beta stocks, systematic risk of equity.

\subsubsection{Mediating Variable: Level of Integrated Reporting Disclosure (IR Score)}

This study uses coverage ratio generated from data processing based on NVIVO 10 software. The independent variable is the level of IR information disclosure in the company report. Disclosure of IR information is measured using percentage of keyword coverage. Percentage of keyword coverage is the percentage of the number of keywords disclosed to the total number of words expressed in the IR report.

The keyword coverage results are a percentage $(\%)$ which means how many keywords are searched for are in a text or file or report. For IR keywords, this study uses content elements from the International Integrated Reporting Council (IIRC) and also refers to research from Haji and Anifowose (2016), Zhou et al. (2017) and Fernando (2018). The keyword consists of standard item extraction required by IIRC to be included in an integrated report version of IIRC. In this study the elaboration of the IR framework was carried out so that the core words and phrases could be taken up enough to reveal the content required by IR including organizational overview and external environment, governance, business model, risks and opportunities, strategy and resource allocation, performance, outlook basis of preparation and presentation, to general reporting guidance.

\subsubsection{Independent Variable: Board of Directors Effectiveness (Board Score)}

The measurement used to measure board of directors effectiveness is by using scoring based on research from Hermawan (2011) which was developed in this study. Score for board of directors effectiveness by using a checklist which captures how the independence, activity, size, and competence characteristics are reflected in the board of directors. There are three additional question points developed, with reference to research from Gupta et al. (2018) and Teti, Del'Aqua, Etro, and Resmini (2016). These additional questions are (1) Are the Chairman and CEO separated? (2) Are the compensation committee composed solely of independent outsiders? (3) Are the nominating committee composed solely of independent outsiders? These three additional questions reflect the independence of the board of directors. Especially for points (1) which is separation of functions between the Chairman and CEO which was not included in the previous research by 
Hermawan (2011) because the research sample was the State of Indonesia which adopted a twotier system. While the other two additional points are questions related to independence from the compensation committee and nomination committee.

The checklists consist of 20 questions for board of directors effectiveness. Each question in the checklist will be scored 1 (Poor), 2 (Fair), or 3 (Good) based on the information disclosed in firm integrated reports. But there are a few questions that have only 2 possible scores (Good or Poor). Maximum score is 60 and minimum 20. The final score is the total sum of score for each characteristic based on the questions on the checklist divided by the maximum score, so value of board of directors effectiveness ranged from 0 to 1 .

\subsection{Method}

This study is a research that uses intervening variables so that it will know the direct and indirect effects of the independent variables on the dependent variable. This study uses the Structural Equation Modeling (SEM) model with the help of the STATA program. The reason for using SEM is because in this program the effects calculation (both direct, indirect, and total) has been provided so as to facilitate users without manual calculation (Wijanto, 2012). SEM is a multivariate analysis that can analyze the relationship of variables in a complex manner (Sarjono \& Julianita, 2015). SEM analysis techniques have powerful properties for processing complex research models that use mediating variables.

\section{RESULTS AND DISCUSSION}

\subsection{Descriptive Statistics}

Based on Table 2, the cost of equity (COE) obtained from Thompson Reuters Database has an average of $6.5 \%$. This indicates that investors in sample countries on average ask for $6.5 \%$ returns on their investments in the capital markets in each country. Minimum value of $0.91 \%$ and maximum value of $17.30 \%$.

BoD effectiveness obtained with an index based on the development of research from Hermawan (2011) has an average of $89.48 \%$. This indicates that the average level of BoD effectiveness in companies in the sample countries is $89.48 \%$. The minimum value of $56.67 \%$ and the maximum value of $100 \%$ is the level of effectiveness of the $\mathrm{BoD}$. Japan is a country that has maximum value in terms of $\mathrm{BoD}$ effectiveness.

The level of integrated reporting (IRScore) disclosure has an average $5.06 \%$ disclosure. It can be concluded that from the overall words contained in integrated reporting, an average of 5.06\% reveals integrated reporting in accordance with the keywords used in this study. The higher coverage ratio indicates the higher the level of disclosure of integrated reporting by the company, the higher the company's commitment in implementing integrated reporting. The lowest integrated reporting disclosure was $0.20 \%$ while the highest disclosure was $9.56 \%$. This small percentage is likely because the sample company is still voluntary in IR disclosure, and not mandatory. So that the company has not been urged to disclose extensively. 
The average profitability (ROA) of companies in the sample country is $3.96 \%$, which means that every 100 dollars in total assets can generate a profit of 3.96 dollars. The lowest ROA was $-0.43 \%$, which is a company that suffered a significant loss of $43 \%$ of total assets. And the highest ROA gains $72 \%$ of total assets.

Investment risk (BETA) data was taken from Thompson Reuters Database. The average risk level of a company's investment in the sample country is $0.91 \%$. This indicates the level of risk borne by an average of $0.91 \%$ in each company in each country. Companies with the smallest risk level of $-0.51 \%$, and the highest risk of $2.39 \%$.

Table 2: Descriptive Analysis

\begin{tabular}{|c|c|c|c|c|c|}
\hline VARIABLE & OBS. & MEAN & STD. DEV. & MIN. & MAX. \\
\hline $\mathrm{COE}$ & 373 & 0,0646 & 0,0236 & 0,0091 & 0,1730 \\
\hline BOARDSCORE & 373 & 0,8948 & 0,0437 & 0,5667 & 1,0000 \\
\hline IRSCORE & 373 & 0,0506 & 0,0085 & 0,0020 & 0,0956 \\
\hline ROA & 373 & 0,0396 & 0,0587 & $-0,4300$ & 0,7203 \\
\hline BETA & 373 & 0,9124 & 0,3941 & $-0,5104$ & 2,3891 \\
\hline $\begin{array}{l}\text { SIZE (Millions of } \\
\text { USD) }\end{array}$ & 373 & $26.265,17$ & $46.864,03$ & 187,0386 & $493.071,00$ \\
\hline SIZE (Ln) & 373 & 23,0325 & 1,3853 & 19,0468 & 26,9239 \\
\hline LEV & 373 & 0,5797 & 0,1977 & 0,1260 & 1,7399 \\
\hline GDP (USD) & 373 & $38.495,52$ & $12.792,37$ & $1.606,04$ & $101.446,80$ \\
\hline \multicolumn{6}{|c|}{$\begin{array}{l}\text { Description: } \mathrm{COE}=\text { Cost of equity requested by investors, BoardScore }=\text { Score of Board of } \\
\text { Directors effectiveness, IRScore = Score of integrated reporting disclosure, ROA = } \\
\text { profitability, BETA }=\text { investment risk, SIZE = company size, LEV = debt level ratio, GDP } \\
=\text { Gross Domestic Product }\end{array}$} \\
\hline $\begin{array}{l}\text { DUMMY } \\
\text { VARIABLE }\end{array}$ & \multicolumn{2}{|c|}{$\begin{array}{l}\text { OBSER } \\
\text { V. }\end{array}$} & \multicolumn{3}{|c|}{$\begin{array}{l}\text { MEAN } \\
\text { (PROPORTION VALUE 1) }\end{array}$} \\
\hline IND & \multicolumn{2}{|l|}{373} & \multicolumn{3}{|l|}{0,6730} \\
\hline LAW & \multicolumn{2}{|c|}{373} & \multicolumn{3}{|c|}{0,7748} \\
\hline \multicolumn{6}{|c|}{$\begin{array}{l}\text { Description: IND = dummy variable, } 1 \text { for manufacturing industry category and } 0 \\
\text { otherwise, LAW = dummy variable, } 1 \text { for the legal system category of a country that } \\
\text { adheres to civil law and } 0 \text { otherwise. }\end{array}$} \\
\hline
\end{tabular}

Company size (SIZE) is measured by the natural logarithm of the company's total assets. The average company in the sample country has a total asset of USD 26 billion with a very large standard deviation of USD 47 billion. This indicates that the data distribution of the company's total assets is quite diverse among companies in each country in the sample of this study. The company with the smallest total assets is USD 187 million while the largest total asset is USD 493 billion. On average, companies in sample countries use liabilities of $57.97 \%$ of total assets as a source of funding. The variation is quite diverse with a standard deviation of 0.20 . Companies that use debt as a source of funding with the smallest value of total assets is $12.60 \%$, and the largest is the leverage level of $173 \%$.

Gross Domestic Product (GDP) in the average company in the sample country is USD 38,496. GDP is the value of the final goods and services produced by various production units in the 
territory of a country within one year. The smallest GDP with a value of USD 1,606, and the largest is USD 101,447. Industry (IND) is a dummy variable with a value of 1 for the manufacturing industry category referring to the research of Kilic and Kuzey (2018) and 0 others. A total of 67.30\% observation or 251 observations included in the manufacturing industry category. LAW is a dummy variable with a value of 1 for the category of countries that follow the civil law system and the other 0 refers to the research of Gupta et al. (2018). $77.48 \%$ of observations or 289 observations fall into the category of countries that follow the civil law system.

\subsection{Analysis Results}

In general the model is valid for use because all models have a Prob $>\mathrm{F}$ value smaller than $\alpha=5 \%$. This research model has a value of Prob $>F=0.011$. In addition, in the testing of multicollinearity, the VIF value does not exceed 0.10 so that the assumption of multicollinearity is not violated.

Table 3: Results of SEM Model (Direct Effect)

\begin{tabular}{|c|c|c|c|c|c|c|}
\hline \multirow[t]{2}{*}{ VARIABLE } & \multicolumn{3}{|c|}{$\begin{array}{c}\text { MODEL 1 } \\
\text { IRScore }_{i t}=\beta_{0}+\beta_{1} \text { BoardScore }_{i t}+ \\
\beta_{2} \text { Size }_{i t}+\beta_{3} \text { ROA }_{i t}+\beta_{4} \mathrm{LEV}_{i t}+ \\
\beta_{5} \mathrm{IND}_{\mathrm{it}}+\beta_{6} \mathrm{GDP}+e_{\mathrm{it}}\end{array}$} & \multicolumn{3}{|c|}{$\begin{array}{c}\text { MODEL 2 } \\
\text { COE }_{\text {it }}=\beta_{0}+\beta_{1} \text { BoardScore }_{i t}+ \\
\beta_{2} \text { IRScore }_{i t}+\beta_{3} \text { Size }_{\text {it }}+\beta_{4} \mathrm{LEV}_{\text {it }}+ \\
\beta_{5} \text { BETA }^{+} \beta_{6} \mathrm{LAW}+\beta_{7} \text { GDP }+e_{\text {it }}\end{array}$} \\
\hline & $\begin{array}{c}\text { EXPECT. } \\
\text { SIGN }\end{array}$ & COEF. & SIG. & $\begin{array}{c}\text { EXPECT. } \\
\text { SIGN }\end{array}$ & COEF. & SIG. \\
\hline IRSCORE & & & & - & $-0,179$ & $0,002 * * *$ \\
\hline BOARDSCORE & + & $-0,013$ & 0,222 & & & \\
\hline SIZE & + & 0,000 & 0,727 & - & 0,000 & 0,808 \\
\hline LEV & + & $-0,001$ & 0,765 & + & 0,000 & 0,958 \\
\hline ROA & + & $-0,004$ & 0,584 & & & \\
\hline IND & + & $-0,001$ & 0,224 & & & \\
\hline BETA & & & & + & 0,047 & $0,000 * * *$ \\
\hline LAW & & & & - & $-0,020$ & $0,000 * * *$ \\
\hline GDP & + & 0,002 & $0,007 * * *$ & - & $-0,012$ & $0,000 * * *$ \\
\hline R2 & & & $3,15 \%$ & & & $84,23 \%$ \\
\hline Prob. F & & & 0,011 & & & 0,011 \\
\hline Observations: & & & 373 & & & 373 \\
\hline
\end{tabular}

*** significant at the level of $\alpha=1 \%$ (one tailed)

$* *$ significant at the level of $\alpha=5 \%$ (one tailed)

* significant at the level of $\alpha=10 \%$ (one tailed)

Description: IRSCORE $=$ score of integrated reporting disclosure, BOARDSCORE $=$ score of board of directors effectiveness, SIZE = company size, natural logarithm of total assets, LEV = total liabilities to total assets ratio, ROA = profitability, total net income to total assets, IND = dummy industry, 1 if manufacturing and 0 otherwise, BETA = investment risk, measured by Capital Assets Pricing Model (CAPM), LAW = dummy variable, 1 if civil law and 0 otherwise, GDP = Gross Domestic Product

Based on table 3, the results of SEM processing in the direct test found that the BoD effectiveness variable has a coefficient of -0.013 , thus indicating a negative effect. The probability value of the BoD effectiveness variable is 0.222 . This value is above the significance level of $5 \%$, thus 
concluding that BoD effectiveness does not have an influence on the variable level of IR disclosure. This result is not in accordance with the prediction so hypothesis 1 is rejected.

For variable IR disclosure rates, based on table 4 , the coefficient value is -0.179 . These results conclude that the IR disclosure level variable has a negative effect on the cost of equity, and this is in line with predictions. The probability value of this variable is 0.002 and below the significance level of $1 \%$, thus indicating that this variable has an influence on the cost of equity. This result is in accordance with the prediction so hypothesis 2 is accepted.

Furthermore, for indirect test results, based on table 4, BoD effectiveness is not proven to have an influence on the cost of equity through the level of IR disclosure. Based on the variable probability value is 0.256 , which is above the $5 \%$ significance level. This result is not as expected so hypothesis 3 is rejected.

Table 4: Results of SEM Model (Indirect Effect)

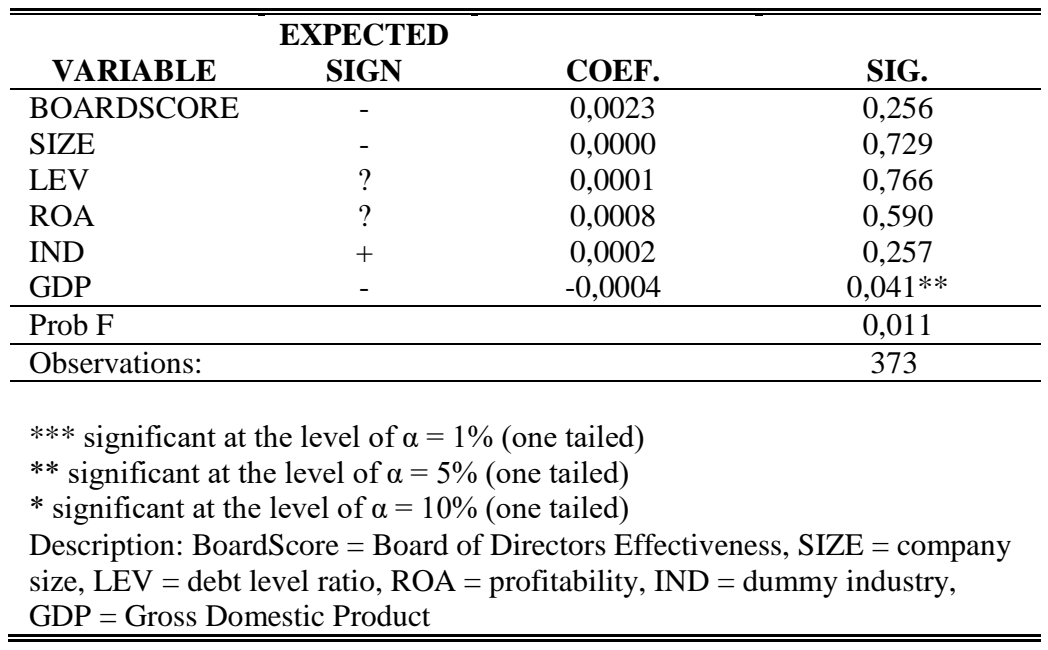

\subsection{Discussion}

Based on the results of empirical testing, Board of Directors effectiveness variables have no significant effect on the level of IR disclosure. This result does not support signaling theory, that good Board of Directors effectiveness will influence companies to manage company resources well, which then becomes a positive signal to external parties that can reduce information asymmetry which in turn will reduce the cost of equity. The results of this study are not in line with Kilic and Kuzey (2018), the findings show that the characteristics of board of directors have a positive effect on firm disclosures. But, on the other hand, research from Kilic and Kuzey (2018) found no significant impact on some of the characteristics of other board of directors such as the size and composition of the board of directors on firm disclosures. This may be due to the increase in public disclosure, all information about the firm will be open to the public, both positive and negative. In line with research from De Villiers et al., (2017) which states that there are several 
factors that prevent firm management from disclosing its IR, among others, the confidentiality of firms that do not want to be exposed to the public and also related to proprietary costs, namely costs incurred because information disclosed by firms can be used by competitors to endanger firm competitive position. On the other hand, $\mathrm{BoD}$ may assume that IR adoption does not increase the substance of the reporting carried out by the firm, as research from Wild and Staden (2013) and Melloni (2015). So, the firm decided not to disclose information (IR). Besides, the existence of an effective Board of Directors does not necessarily improve the disclosure of integrated reporting. Perhaps this is due to research samples that use companies which are still voluntary in disclosing their integrated reporting.

Regarding the relationship between the level of IR disclosure and equity costs, it is evident that the level of IR disclosure has a negative and significant effect on cost of equity. This result is consistent with signaling theory which states that companies must disclose voluntary information that is more extensive than just disclosing mandatory information if they want to get the benefits and trust from investors, in this case the benefits of lower cost of equity. The firm is motivated to disclose integrated reporting and hope that it will reduce information asymmetry between management and external parties. The decrease in information asymmetry has the effect of reducing the cost of supervision by investors, thereby reducing the cost of equity. These results also support previous research from Dhaliwal et al. (2014) who examined the disclosure of the firm's voluntary Corporate Social Responsibility (CSR) reporting conducted at the country level and found a negative effect of CSR disclosure on cost of equity. This result also supports previous research from $\mathrm{Ng}$ and Rezaee (2015) and García-Sánchez and Noguera-Gámez (2017), that the level of IR disclosure has a significant effect in reducing the cost of equity. Schoenfeld's (2017) study also says that disclosure of voluntary reporting will increase stock liquidity which ultimately decreases the company equity costs.

For the indirect relationship related to the effect of Board of Directors (BoD) effectiveness on the cost of equity through the level of disclosure of IR is not proven to have a significant effect. Although the level of extensive integrated reporting disclosure has been proven to reduce the cost of equity, if it is seen from the effect of the Board of Directors effectiveness on level of IR disclosure, it is not proven to be significant. So that the level of disclosure of integrated reporting is not proven to mediate the relationship between the effectiveness of the Board of Directors on cost of equity. In general, the indirect relationship between $\mathrm{BoD}$ effectiveness to cost of equity mediated by IR disclosure is not supported in this study. The results are also not in accordance with the signal theory which states that firms must be able to disclose voluntary information rather than just disclosing mandatory information if they want to get benefits and trust from investors, in this case the benefits are lower equity costs. However, these results are in line with previous studies which say that the relationship between good corporate governance practices and equity costs is still in debate, it all depends on how corporate governance can regulate the level of variation related to market risk that exists between the company and also at the level country (Chen, Chen \& Wei, 2009). 


\section{CONCLUSION}

This study examines the direct and indirect relationships between board of directors (BoD) effectiveness, the level of IR disclosure and also cost of equity with the variable level of IR disclosure as a mediating variable. Board of directors effectiveness is seen from several components including independence, activity, size and competence. This research method uses secondary data which is then tested with a model of structural equation modeling (SEM).

The results of this study are in accordance with the research of $\mathrm{Ng}$ and Rezaee (2015) that the level of IR disclosure has a significant effect in reducing the cost of equity. However, this study cannot prove the relationship between board of directors effectiveness and the level of IR disclosure. Probably due to research samples that use companies that are still voluntary in disclosing their integrated reporting. So the board of directors felt it was not necessary to disclose IR extensively.

This study also cannot prove the indirect relationship that expects board of directors effectiveness to influence the decrease in the company cost of equity through the level of disclosure of integrated reporting. Although the level of extensive integrated reporting disclosure has been proven to reduce the cost of equity borne by the company, if it is seen from the effect of the board of directors effectiveness on level of IR disclosure, it is not proven to be significant.

The results of this study have implications for regulators in terms of considering to implementing a mandatory policy for IR disclosure. Because according to the results of this study it is proven that IR disclosure has a significant influence in reducing cost of equity. This research has several limitations. First, the use of samples only covers a limit companies. Second, IR measurement uses NVIVO 10 software by searching for keywords related to IR. This keyword search only captures how much information is disclosed but cannot assess how the quality of the information is disclosed. Third, this study only uses one measurement in calculating the cost of equity. The researcher suggests several subsequent studies, using a sample with a larger sample. Assessing the quality of the IR by using manual checklists through indexing in order to truly describe the level of IR disclosure and quality. And add a type of measurement in calculating the cost of equity, for example with Ohlson's model and so on.

\section{REFERENCES}

Baboukardos, D., \& Rimmel, G. (2016). Value relevance of accounting information under an integrated reporting approach: a research note. Journal of Accounting and Public Policy, 35(4), 437-452.

Barth, M. E., Cahan, S. F., Chen, L., \& Venter, E. R. (2017). The economic consequences associated with integrated report quality: Capital market and real effects. Accounting, Organizations and Society, 62(2017), 43-64. doi:10.1016/j.aos.2017.08.005

Berndt, T., Bilolo, C., \& Muller, L. (2014, April 28-29). The Future of Integrated Reporting: Analysis and Recommendations. $4^{\text {th }}$ Annual International Conference on Accounting and Finance (AF 2014) (pp. 195-206). Phuket, Thailand. 
Blanco, B., Lara, J. M. G., \& Tribo, J. A. (2015). Segment disclosure and cost of capital. Journal of Business Finance and Accounting, 42(3-4), 1-45.

Chen, K. C. W., Chen, Z., \& Wei, K. C. J. (2009). Legal protection of investors, corporate governance, and the cost of equity capital. Journal of Corporate Finance, 15(3), 273-289. doi: 10.1016/j.jcorpfin.2009.01.001

Cheynel, E. (2009). A theory of voluntary disclosure and cost of capital (Unpublished doctoral dissertation). Carnegie Mellon University, Pittsburgh, Pennsylvania. Retrieved from https://www.cmu.edu/tepper/programs/phd/program/assets/dissertations/2009-financialeconomics-cheynel-dissertation.pdf

Deloitte. (2014). Integrated reporting in the Netherlands. Retrieved from https://integratedreporting.org/resource/deloitte-integrated-reporting-in-the-netherlands/

De Villiers, C., Hsiao, P.-C. K., \& Maroun, W. (2017). Developing a conceptual model of influences around integrated reporting, new insights and directions for future research. Meditari Accountancy Research, 25(4), 450-460.

Dias, A., Rodrigues, L. L., \& Craig, R. (2017). Corporate Governance Effects on Social Responsibility Disclosures. Australasian Accounting, Business and Finance Journal, 11(2), 3-22. doi:10.14453/aabfj.v11i2.2

Eccles, R. G. \& Krzus, M. P. (2010). One Report: Integrated Reporting for a Sustainable Strategy. New York: John Wiley and Sons.

Eccles, R. G., \& Serafeim, G. (2014). Corporate and Integrated Reporting: A Functional Perspective. Harvard Business School Working Paper No. 14-049.

Emanuele, C. (2016). Beyond carbon pricing: the role of banking and monetary policy in financing the transition to a low-carbon economy. Ecological Economic, 121, 220-230.

Ernst \& Young Global Limited (EY). (2014). EY's excellence in integrated reporting awards 2014: a survey of integrated report from South Africa's top 100 JSE-listed companies and top 10 state-owned companies. Retrieved from_https://integratedreporting.org/resource/eysexcellence-in-integrated-reporting-awards-2014/

Fernando, K. (2018). Value relevance of sustainability reporting information and integrated reporting: evidence from South Africa (Unpublished Master Thesis). Universitas Indonesia, Depok, Indonesia.

Frías-Aceituno, J. V., Rodríguez-Ariza, L., \& García-Sánchez, I. M. (2013). Is integrated reporting determined by a country's legal system? An exploratory study. Journal of Cleaner Production, 44, 45-55. doi:10.1016/j.jclepro.2012.12.006

García-Sánchez, I. M., \& Noguera-Gámez, L. (2017). Integrated information and the cost of capital. International Business Review, 26(5), 959-975. doi: 10.1016/j.ibusrev.2017.03.004

Gupta, K., Krishnamurti, C., \& Tourani-Rad, A. (2018). Financial Development, Corporate Governance and Cost of Equity Capital. Journal of Contemporary Accounting \& Economics, doi: 10.1016/j.jcae.2018.02.001

Haji, A. A., \& Anifowose, M. (2016). Audit committee and integrated reporting practice: does internal assurance matter? Managerial Auditing Journal, 31(8/9), 915-948.

Hermawan, A. A. (2011). The Influence of Effective Board of Commissioners and Audit Committee on The Informativeness of Earnings: Evidence From Indonesian Listed Firms. Asia Pacific Journal of Accounting and Finance, 2(1), 1-38.

Hoque, M. E. (2017). Why Company Should Adopt Integrated Reporting. International Journal of Economics and Financial Issues, 7(1), 241-248. 
International Integrated Reporting Council (IIRC). (2011). Towards Integrated Reporting: Communicating Value in the 21st Century. Retrieved from https://integrated reporting.org/wp-content/uploads/2011/09/IR-Discussion-Paper-2011_spreads.pdf

International Integrated Reporting Council (IIRC). (2013). The International Integrated Reporting Framework. Retrieved from https://integratedreporting.org/wp-content/uploads /2021/01/InternationalIntegratedReportingFramework.pdf

Kilic, M., \& Kuzey, C. (2018). Determinants of forward-looking disclosures in integrated reporting. Managerial Auditing Journal, 33(1), 115-144.

Klein, A. (2002). Audit committee, board of directors' characteristics and earnings management. Journal of Accounting and Economics, 33, 375-400.

Lee, K. W., \& Yeo, G. H. H. (2016). The association between integrated reporting and firm valuation. Review of Quantitative Finance and Accounting, 47(4), 1221-1250.

Lintner, J. (1965). Security prices, risk, and maximal gains from diversification. The Journal of Finance, $X X(4), 587-615$.

Lipton, M., \& Lorsch, J. W. (1992). A Modest Proposal for Improved Corporate Governance. The Business Lawyer, 48(1), 59-78.

Mallin, C. A. (2013). Corporate governance ( $5^{\text {th }}$ ed.). Oxford: Oxford University Press.

Mazzotta, R., \& Veltri, S. (2014). The relationship between corporate governance and the cost of equity capital. Evidence from Italian stock exchange. Journal of Management and Governance, 18(2), 419-448.

Melloni, G. (2015). Intellectual capital disclosure in integrated reporting: an impression management analysis. Journal of Intellectual Capital, 16(3), 661-680.

Mossin, J. (1969). Security pricing and investment criteria in competitive markets. The American Economic Review, 59(5), 749-756.

$\mathrm{Ng}$, A. C., \& Rezaee, Z. (2015). Business sustainability performance and cost of equity capital. Journal of Corporate Capital, 34, 128-149.

Organisation for Economic Co-operation Development (OECD). (2015). G20/OECD Principles of Corporate Governance. Paris: OECD Publishing.

PricewaterhouseCoopers AG (PWC). (2012). Integrated Reporting: The Future of Corporate Reporting. Retrieved from https://www.pwc.de/de/rechnungslegung/assets/integratedreporting-die-zukunft-der-berichterstattung.pdf

PricewaterhouseCoopers Inc (PWC). (2013). The Value Creation Journey: A Survey of JSE Top 40 Companies' Integrated Reports. Retrieved from https://www.pwc.co.za/en/ assets/pdf/integrated-reporting-august-2013.pdf

Qin, L., \& Tan, L. (2007). An Empirical Analysis of The Relation Between Board Independence and Earnings Management. Wuhan University. Science Innovation Academic Frontier, 327-331. Retrieved from http://www.seidatacollection.com/upload/product/200911 /2007qyczhy2z2a4.pdf

Saini, J. S., \& Herrmann, D. (2013). Cost of Equity Capital, Segment Disclosure, And Information Asymmetry. Working Paper. Western Michigan University, Oklahoma State University.

Sarjono, H., \& Julianita, W. (2015). Structural Equation Model (SEM): Sebuah Pengantar, Aplikasi untuk Penelitian Bisnis. Jakarta: Penerbit Salemba Empat.

Schoenfeld, J. (2017). The effect of voluntary disclosure on stock liquidity: New evidence from index funds. Journal of Accounting and Economics, 63(1), 51-74. doi: 10.1016/j.jacceco.2016.10.007

Sharpe, W. F. (1964). Capital asset prices: a theory of market equilibrium under conditions of risk. 
The Journal of Finance, XIX(3), 425-442.

Teti, E., Dell'Acqua, A., Etro, L., \& Resmini, F. (2016). Corporate governance and cost of equity: empirical evidence from Latin American companies. Corporate Governance: The International Journal of Business in Society, 16(5), 831-848. doi: 10.1108/CG-02-20160028

Yoo, J. \& Semenenko, I. (2012). Segmen Information Disclosure and the Cost of Equity Capital. Journal of Accounting-Business and Management, 19(1), 103-123.

Van Zyl, A. S. (2013). Sustainability and Integrated Reporting in the South African Corporate Sector. International Business and Economics Research Journal, 12(8), 903 - 926.

Velte, P., \& Stawinoga, M. (2016). Integrated reporting: The current state of empirical research , limitations and future research implications. Journal of Management Control, 28(3), 275 320. doi: 10.1007/s00187-016-0235-4

Villiers, C. de. (2014). Integrated reporting: Insights, gaps and an agenda for future research. Accounting, Auditing \& Accountability Journal, 27(3), 1042-1067.

Wijanto, S. H. (2012). Metode Penelitian Menggunakan Structural Equation Modeling dengan LISREL 9. Depok, Jakarta: Lembaga Penerbit Fakultas Ekonomi Universitas Indonesia.

Wild, S, \& Staden, V. C. (2013). Integrated reporting: An initial analysis of early reporters. Paper presented at the Massey University Accounting Research Seminar, Auckland.

Zhou, S., Simnett, R., \& Green, W. (2017). Does Integrated Reporting Matter to the Capital Market? 53(1), 94-132. doi: 10.1111/abac.12104 